\title{
Strategic Decision Process in SME's Context: A New Perspective Using Indigenous, Institution, Firm, and Environment Characteristics
}

\begin{abstract}
Submitted 18/06/19, $1^{\text {st }}$ revision 23/07/19, $2^{\text {nd }}$ revision 15/10/19, accepted 01/11/19
Jean Richard Jokhu ${ }^{1,2}$, Rofikoh Rokhim ${ }^{1}$, Riani Rachmawati ${ }^{1}$, Mohammad Hamsal ${ }^{3}$

\section{Abstract:}

Purpose: This paper aimed to contribute to fill the gap of the strategic decision-making process framework in the context of an SME. Not only adds a new perspective in the strategic decision-making process framework, but also suggests new perspectives of firms, environment, institutions and indigenous characteristics as the new approach that magnifies strategic decision-making's models with respect to SMEs' scale.

Design/methodology/approach: The purposive sampling method has been used in this study. First, we used the CEO as the respondent to fulfill decision involvement criteria. Second, the samples were selected based on the criterion that the last project of this SME has finished in the last 3 years. Then we choose a project bidding decision from construction SMEs to minimize decision bias. Finally, from 4253 SMEs listed in Papua, we finished with 350 respondents. The study had collected 156 SME's project decisions.

Findings: The Heuristic decision, that previously neglected because of information bias and short decision process, deemed to be the most profound dimension in strategic decision making and demonstrated significant results toward SMEs' project performance. All variables, exclude institution, shows good and significant results. The research uses project decision in the construction industry as the main unit analysis.

Practical implications: Exploring strategic decision-making theory in the SME context could convince SME's CEO to evaluate its external factors before taking a project, processing all the information needed toward its project performance.

Originality/value: This heuristic measurement scale is the first valid and reliable tool, based on several previous researches (Busenitz and Barney, 1997; Artinger et al., 2015), that could identify and measure the heuristic process in a strategic decision process.
\end{abstract}

Keywords: Heuristic decision process, environment characteristics, project performance.

JEL codes: O13, Q20, Q28.

Article type: Research study.

\footnotetext{
${ }^{1}$ Department of Management, Economics and Business Faculty, Universitas Indonesia.

${ }^{2}$ Department of Management, President University, e-mail:

${ }^{3}$ Doctoral Research Program, Binus University.
} 


\section{Introduction}

The context of strategic decision-making has been a popular topic in strategic process in strategic management literature (Elbanna, Benedetto \& Gherib, 2015; Shepherd \& Rudd, 2014). Over the years, several researchers have conducted multiperspective research regarding this subject, whether for an internal context such as firm resources, top management teams or for an external context, i.e., environment (Papadakis et al., 1998; Wiklund \& Shepherd, 2005). Prior research states that the external characteristic is based on the environment context (Dess \& Beard, 1984; Fredrickson \& Iaquinto, 1989; Dean \& Sharfman, 1996; Luo, 2005; Souitaris \& Maestro, 2010). However, many researchers still have not arrived at any consensus concerning the strategic decision-making context and decision process which actually affects decision-making.

Furthermore, prior research ascertained that decision-making in small medium enterprises (SME) differs from the big firms, and the most common determinants used are always the same, such as the top management team (TMT), environment, and firm resources (Liberman-Yaconi, Hooper \& Hutchings, 2010; Shepherd \& Sharfman, 2011). As the literature on strategic decision-making keeps developing, this research offers another perspective of decision-making process that result on better economic performance of a firm when determined by uncertain environment characteristics, firm characteristics, indigenous characteristics and institutional characteristics.

To explore the argument above, we designed a study which combines four factors to explain different approaches that influence strategic decision-making in SMEs (Boubakri et al., 2013; Jarkas, Mubarak \& Kadri, 2014; Lin et al., 2015). First perspective is to answer the relationship of this perspective indigenous people who create a different outcome in strategic decision-making. Second, identified how the relationship of the government and SME witherd strategic decision-making process. These two characteristics provide a new approach as a determinant of the strategic decision-making. Third, we incorporated environment as the supporting element of the strategic decision-making process that need to explore more especially in the SME. Fourth, we provide new perspective in firm characteristics that considers the role of firm context i.e., in SME decision process (Elbanna, Dibenedetto and Gherib, 2015). The perspectives concerning the environment and firm characteristics are commonly considered by research on SDMP (Elbanna, 2018; Elbanna \& Said, 2007; Papadakis, 2006). However, such research has always employed manufacturers or big firms in order to describe decision-making. Furthermore, this research also focused on strategic decision-making process effect on firm project performance.

This study aimed to measure the extent of these factors, firm, environment, indigenous and institution characteristics, contribute to the strategic decisionmaking process in SME project performance (Liberman-Yaconi et al., 2010). Therefore, the study tries to calculate the effect of decision factors on strategic 
Strategic Decision Process in SME's Context: A New Perspective Using Indigenous, Institution, Firm, and Environment Characteristics

decision making process in project performance using structural equation modelling (SEM).

\section{Literature Review}

\subsection{Strategic Decision Making in SMEs}

Strategic decision making was defined as a phase that involves making important decisions for a firm's survival (Eisenhardt \& Bourgeois, 1988; Elbanna, 2018; Reggers et al., 2016; Schwenk, 1995). Schwenk (1985 and 1995) explained two kinds of decision-making dimensions: rationality and bounded rationality. Both are the decision process that mostly apparent in individual decision making differentiate by accumulation of information in the decision process (Epstein, 1995; Artinger et al., 2015).

First, for rationality, decision-making employs comprehensive and systematic data processing to arrive at a decision (Papadakis et al., 1998; Rajagopalan et al., 1993). On the other hand, for bounded rationality, the outcomes of decision-making result from incomplete information. Hence, it is concerned with a decision maker's satisfaction while processing an incomplete information (Basel \& Brühl, 2013; Krabuanrat \& Phelps, 1998; Schwenk, 1985). Bounded rationality, which occurs commonly during decision-making, is a heuristic process (Guercini, La Rocca, Runfola \& Snehota, 2015; Liberman-Yaconi et al., 2010). A heuristic process is a manifestation of decision-making that is based on the collection of incomplete information and overconfidence regarding that particular decision-making (Åstebro \& Elhedhli, 2006; Busenitz \& Barney, 1994; Gigerenzer \& Gaissmaier, 2010; Weathers, Sharma \& Niedrich, 2005). Although these two decision-making aspects are opposite to each other, both of them, i.e., rationality and bounded rationality, can overlap or even combine with one another (Mintzberg, 1973; Mintzberg, Raisinghani \& Theoret, 1976). Similarly, Liberman-Yaconi et al. (2010) explain that heuristic and rational decision-making are entangled with each other. Therefore, these should be employed to better explain the strategic decision-making of small firms. Hence, in the context of this study, rationality and heuristic decision-making were used as a dimension to better explain the same.

Deligianni et al. (2015) also finds strategic decision making into rationality and bounded rationality. Although the argument stated that rationality is the most dominant factors for strategic decision. The argument is investing resource, time and effort to complete the information when making a strategic decision does not "create waste" but is a useful activity. Therefore, by having a rational process firm can also increase control of firm performance because it ensures that project taken will be managed based on the information gathered. Brouthers et al. (1998) and Artinger et al. (2015) find strategic decision in small firms dominated by the simple decisionmaking process. They argued that as the firms getting bigger the process of decision making will be much more complex, therefore small firms posit simple but the 
analytical decision-making process. This entanglement provides fertile ground on which rational and heuristics can flower, in order to cover incomplete information in an uncertain environment.

\subsection{Project Performance}

In the context of this study, firm performance is projected by project performance, which defined by Elbanna (2013) as an economic outcome derived from decisionmaking. Strategic decision-making has been identified to facilitate environmental and firms' characteristics towards better decision-making (Rajagolapan et al., 1993). In relation to this study on bidding, decision makers should conduct their analysis based on the current information available on the environment and the firms' conditions pertaining to decision-making. In order to find the best suited project for such firms, still related to the project's bidding, setting high prices will result in losing the competition, whereas setting low prices will result in a reduction of the project's quality due to the interception of cost minimisation (Ashmos, Duchon \& McDaniel, 1998; Hughes, Tippett \& Thomas, 2004; Trigunarsyah, 2004).

In the context of construction, Ahmad (1988) corroborates that proper use of rational and heuristic decision-making benefit decision construction in the bidding process by simplifying project bidding decision with available information and experience, the firm can easily posit its position in bidding competition and securing its project in case of limited bidding time. The construction firms will take a job based on their capacity, hence their project will be manageable and increase their project performance before overdue. Both rational and heuristic can increase firm processing options toward available project. Therefore, having a pathway of processing increase firm bidding process capability through the entanglement of the strategic decision-making process (Liberman-Yaconi et al., 2010; Artinger et al., 2015). Therefore, the following hypothesis has been developed:

H1: Strategic decision-making will share a positive relationship with the project performance.

\subsection{Firm Characteristics}

According to Barney (1990), a firm's resources reflect on its strategic options. Rajagolapan (1990) and Shepherd (2014) explain the way in which important firms condition themselves towards decision-making. Firms with better resources generate better performances in terms of decision-making and information gathering. This is because for small firms, comprehensive information becomes a luxury that they cannot afford (Brouthers et al., 1998; Busenitz \& Barney, 1994). Brouther and Brouther (1998) explained that at the SME level, a firm's structure has an impact on its decision-making. The more centralised the firm, the faster the decision-making occurs. Furthermore, bigger firms deal with more complex current political behaviour, while small companies tend to focus on the CEO's interests and 
confidence on processing a piece of information (Jansen et al., 2011; Palich \& Bagby, 1995; Stewart et al., 1999). Therefore, the following hypothesis has been developed in this regard:

H2: Firm characteristics will account for a significant amount of variance in strategic decision-making.

\subsection{Environment Characteristics}

They constitute the condition or situation in which a decision is taken (Ashraf, Hassan, Ghafoor \& Aslam, 2015; Dess \& Beard, 1984; Elbanna, 2015; Elbanna \& Child, 2007; Papadakis, 1998). Elbanna (2015) explained the important factor of the environment with respect to decision-making, while several studies have established the important factors of the same (Aravopoulou, 2018; Garvin, 2009; Gigerenzer \& Marewski, 2015; Papadakis, 2006; Price \& Newson, 2003). The previous studies argue that the condition of the environment prolongs a firm's capability to set the best price with regard to a project decision (Bageis \& Fortune, 2009; Oo, Lo \& Lim, 2012). For instance, low competition results in less price flexibility, because fewer companies bid against the price set by a particular company. On the other hand, high competition will reduce a firm's chance to generate higher profits. As explained by Oo, Lo \& Lim (2012), better environment characteristics provide abundant resources and human capital, while a hostile environment reduces strategic decision options for construction SME. Furthermore, fluctuation of material prices causes inflexibility in the bidding prices. Based on this argument, the following hypothesis has been developed:

\section{H3: Environment characteristics will account for a significant amount of variance in strategic decision-making.}

\subsection{Indigenous Characteristics}

These are defined by Warokka (2014) as the degree to which local people perceive their local culture as beliefs that should be applied in their daily lives. In this study, indigenous people are people who lived in, their land through time, from the past to the present (Béteille, 1998; Lin et al., 2015; Rante \& Warokka, 2012). These people tend to obstruct the changes brought in by new people. As in the case of Indonesia, many of them demonstrate negative behaviour towards changes, under the influence of their tribes (Rante, 2010). Similarly, Lin et al., (2015) in their project-based research, asserted that the role of indigenous people in government projects can influence the project performance. The urgency of for reconciliation between the government and indigenous people increases their understanding of project benefits. The presence of indigenous people suggests their influence in strategic decisionmaking. The more indigenous people regard their own cultural values, the higher their propensity to clash against undergoing projects (Heard et al., 2017; Lindsay, 
2005). Thus, this study views indigenous people as the new perspective on shaping strategic decision-making. Based on this argument, we formulate this hypothesis:

H4: Indigenous people will account for a significant amount of variance in strategic decision-making.

\subsection{Institutional Characteristics}

These characteristics are defined as the rules or regulations set in order to control people or the way organisations interact with one another (Doran \& Ryan, 2012; Farashahi \& Hafsi, 2009; Moser et al., 2014; Peng, 2002). Governments have proven to influence a firm's strategic decisions (Huang, 2009). Similarly, Ling and Li (2012) as well as Farashahi and Hafsi (2009) asserted that the relationship with the government prolongs a firm's strategic decision option. Doran and Ryan (2012) stated that the influence of regulation on implementing a limitation of firms results in the development of long strategic decisions that are processed because the construction firm needed to adapt to a new rule, collect new information, and take a decision based on this new regulation. Elbanna and Child (2007) explained the effect of a new regulation that creates new attributes or factors that can limit the process of strategic decision-making. This argument leads to the following hypothesis:

\section{H5: Indigenous people will account for a significant amount of variance in strategic decision-making.}

\section{Research Methodology}

The sampling method used in this research was purposive sampling for all small medium construction firms with less than 500 employees, total asset no more than 10 billion rupiah, collected from the construction sector specialazing in bridge and road construction projects, a total population of 3.957 companies of which 156 participated in the survey. The response rate is high considering the nature of the construction firm's location which is unreachable and the fact that CEOs or company owners never supervised construction project directly. Compare to previous researches, 145 this number of participants considered to be high.

The research considers project decision as its unit analysis. The CEOs were asked to name the recent finished project within the last 5 years. Based on Papadakis (2002) to minimise distortion and memory failure, we asked CEOs for the last 2 - 3-year project decisions. Before the pre-test conducted in December 2017, the question had through face validity with several experts, academics, and several construction firm CEOs. This is for ensuring all indicators in this research applicable for construction firms' context. A total of 30 constructions SMEs was collected for the pre-test. After that, the real test was distributed by The Civil Ministry Officer to construction SME CEOs directly, while the CEOs of construction firms waiting for construction 
Strategic Decision Process in SME's Context: A New Perspective Using Indigenous, Institution, Firm, and Environment Characteristics

business licence extension and registering their project bidding in province civil ministry department.

This study used a convenience sampling, in conjunction with the questionnaire responses collected by the local association and local government staff, for all construction companies that wanted to extend their construction certification in Papua. Data was collected from March until September 2017. By this time, the researchers had gathered 211 responses among the 300 questionnaires distributed in the area. From all the responses, only 156 were valid, with a response rate of $52 \%$, wherein $95 \%$ of the responses received are from a construction firm in Papua.

For the firm size category, about $13 \%$ of them were SMEs with their total assets worth less than 200 million. Moreover, 28\% was from SMEs with total asset worth between Rp. 201-350 million, 12\% from SMEs with assets worth between Rp. 351500 million, $29 \%$ from SMEs with assets worth between Rp. 501 million to 2 billion, and 12\% from SMEs with assets worth above Rp. 2 billion. Almost all of the 156 construction companies were SME firms, wherein $78 \%$ were self-owned SMEs and $17 \%$ were not self-owned ones. Most of the construction SMEs had considerable experience in their respective fields; some were less than 5 years old (27\%), 5-10 years old (52\%), and 11-20 years old (15\%), while others had more than 20 years of experience (2\%) in construction. In terms of the demographic category, most of the respondents were male $(69 \%)$ and only 43 respondents were female $(27 \%)$. The average age of the respondents was between 30-40 years. This research demonstrates that the project performance was influenced by strategic decisionmaking, and most exponential findings state that strategic decision-making in construction firms was dominantly affected by heuristic decision-making (standard loading factor $=0.99$ ).

This study was based on strategic decision-making framework from Rajagopalan et al. (1993). Strategic decisions are the types of decision that have a significant impact on a firm's survival (Eisenhardt \& Zbaracki, 1992). Therefore, this study focused on SME construction firms' project bidding decisions, because construction SMEs highly depend on a project performance for their survival (Ballesteros-Pérez \& Skitmore, 2016). Based on previous empirical research's conclusions, academics were prompted to conduct research in developing countries (Arend et al., 2016; Åstebro \& Elhedhli, 2006; Elbanna \& Fadol, 2016; Papadakis, 2006).

The dimension of firm characteristics was measured using three indicators: firm structure, resource, and past performance (Elbanna \& Child, 2007; Shepherd \& Rudd, 2014). On the other hand, the dimension environment characteristics were derived from the following three indicators: threat, heterogeneity, and complexity (Elbanna \& Fadol, 2016; Dean \& Sharfman, 1996). As for the dimension strategic decision-making, we used two dimensions: rationality and heuristic decision-making (Liberman-Yaconi et al., 2010). The last dimension was project performance, and this research used previous results to assess by using the following factors: time, 
cost, and schedule regarding the project finished (Arend et al., 2016; Hughes et al., 2004). All variable measurements are available in Figure 1.

\section{Results}

Overall, the measurements provided in Table 1 show a satisfactory degree of both validity and reliability. Following prior research, we also used the comparative fit index (CFI) and the Tucker-Lewis index (TLI), root mean square error of approximation (RMSEA) as indicators of absolute fit (Elbanna, 2015; Elbanna \& Fadol, 2016; Hu \& Bentler, 1999). Predominantly, the measurement models presented in Figure 1 show an absolute fit, and more importantly, all measurements show a satisfactory degree of standardised factor loading, which is higher than the recommended value of 0.5 (Hair, Hult \& Ringle, 2014).

Table 1. Descriptive scales and construct correlation, average variance extracted, and construct reliability

\begin{tabular}{|l|l|l|l|l|l|l|l|}
\hline Variables & $\begin{array}{l}\text { Me } \\
\text { an }\end{array}$ & SD & SDMP & $\begin{array}{l}\text { Firm } \\
\text { Charact } \\
\text { eristic }\end{array}$ & $\begin{array}{l}\text { Institutio } \\
\text { n } \\
\text { Characte } \\
\text { ristic }\end{array}$ & $\begin{array}{l}\text { Indigeno } \\
\text { us } \\
\text { Character } \\
\text { istic }\end{array}$ & $\begin{array}{l}\text { Environme } \\
\text { nt } \\
\text { Characteris } \\
\text { tic }\end{array}$ \\
\hline SDMP & 5.38 & 0.70 & 1.00 & & & & \\
\hline $\begin{array}{l}\text { Firm } \\
\text { Characteristic }\end{array}$ & 4.94 & 1.19 & $-.471^{* *}$ & 1.00 & & & \\
\hline $\begin{array}{l}\text { Institution } \\
\text { Characteristic }\end{array}$ & 4.15 & 1.77 & -0.15 & 0.08 & 1.00 & & \\
\hline $\begin{array}{l}\text { Indigenous } \\
\text { Characteristic }\end{array}$ & 4.45 & 1.39 & 0.06 & 0.00 & 0.00 & 1.00 & $.454^{* *}$ \\
\hline $\begin{array}{l}\text { Environment } \\
\text { Characteristic }\end{array}$ & 4.96 & 1.28 & 0.14 & $.208^{* *}$ & $-.245^{* *}$ & 1.00 \\
\hline $\begin{array}{l}\text { Average } \\
\text { Variance } \\
\text { Extracted }\end{array}$ & & & 0.66 & 0.50 & 0.61 & 0.68 & 0.66 \\
\hline $\begin{array}{l}\text { Construct } \\
\text { Reliability }\end{array}$ & & & 0.96 & 0.91 & 0.86 & 0.91 & 0.91 \\
\hline
\end{tabular}

Note: **Correlation is significant at the 0.01 level (two-tailed).

*Correlation is significant at the 0.05 level (two-tailed).

To examine all the variables' construct validity and reliability, at first, we need to reduce the large set of variables using the confirmatory factor, in order to determine latent variable scoring for the structural equation analysis (Elbanna et al., 2013; Elbanna \& Fadol, 2016). There is a requirement for validity and reliability tests according to Hair et al. (2014). First, all the variables should have more than 0.5 loading factor for validity, more than 0.5 construct reliability, and greater than 0.5 average variance extracted, as depicted in Table 1. Furthermore, Table 1 shows that no correlation exceeds the correlation threshold, which is 0.7 (Hair et al., 2014). Therefore, all the variables can be included in the subsequent analysis. 
Strategic Decision Process in SME's Context: A New Perspective Using Indigenous, Institution, Firm, and Environment Characteristics

Figure 1. Results of the SEM analysis

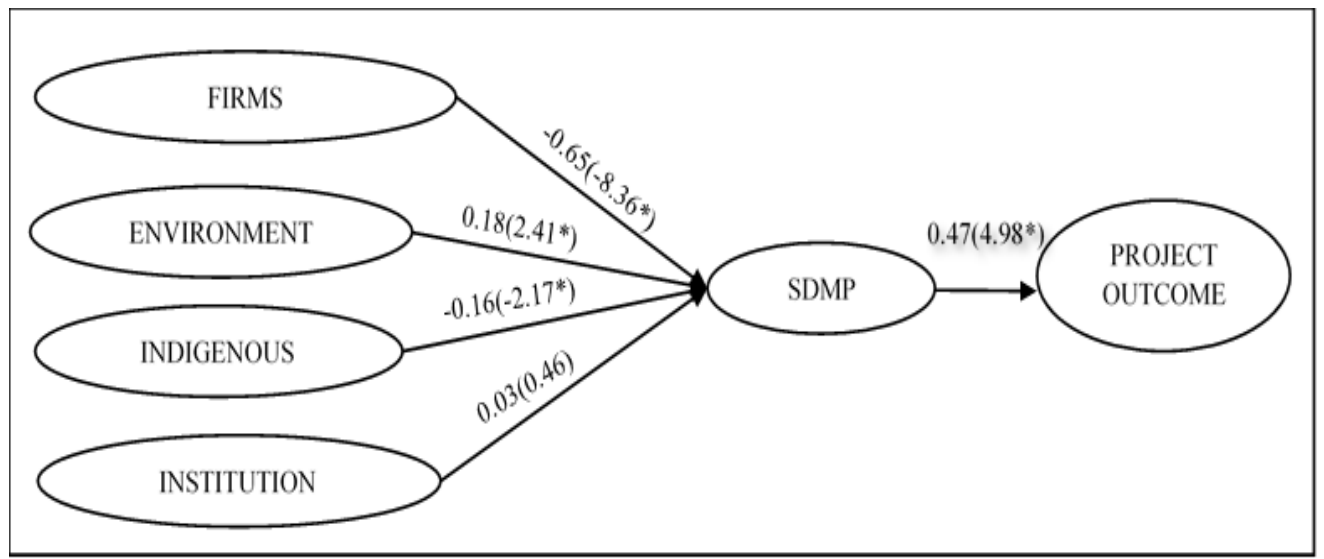

Note: *significant t value (two tailed); GOFI = RMSEA 0.00; NFI 1.00: TLI 1.00.

At the following stage, this research applied a structural equation model for path analysis. A similar analysis was conducted to corroborate the effect of strategic decision-making on the project performance on Figure 1. Subsequently, five significant relationships were found in Table 2 .

Table 2. Summary of hypothesis tests

\begin{tabular}{|c|c|c|c|c|c|}
\hline Hypothesis & Variables & $\beta$ & $\begin{array}{l}\text { t- } \\
\text { value }\end{array}$ & $\begin{array}{l}\text { Statistical } \\
\text { hypothesis }\end{array}$ & $\begin{array}{l}\text { Research } \\
\text { hypothesis }\end{array}$ \\
\hline H1 & $\begin{array}{ll}\text { SDMP } & >\text { Project } \\
\text { performance } & \end{array}$ & 0.47 & 4.98 & Significant $(+)$ & Accepted \\
\hline $\mathrm{H} 2$ & Firm - > SDMP & $\begin{array}{l}- \\
0.65\end{array}$ & -8.36 & Significant (-) & Accepted \\
\hline $\mathrm{H} 3$ & Environment - > SDMP & 0.18 & 2.41 & Significant $(+)$ & Accepted \\
\hline $\mathrm{H} 4$ & Institution - > SDMP & 0.03 & 0.46 & Not Significant & Not Accepted \\
\hline H5 & Indigenous - > SDMP & $\begin{array}{l}- \\
0.16\end{array}$ & -2.17 & Significant (-) & Accepted \\
\hline
\end{tabular}

\section{Discussion}

Overall, the SEM output shows five significant correlations between the latent variables. These findings prove that strategic decision-making could improve the project performance based on the firm, environment, and indigenous characteristic. In addition, several findings prove the worthiness of this research. Context, variables, and concept can serve as virtues for a research (Makadok, Burton \& Barney, 2018), hence the findings, or the novelty, of this research have been stated below.

First, this study's novelty was its research context. This research used SMEs' perspective towards decision-making, especially that of project-based firms. This new context provides new perspectives pertaining to the decision-making theory that 
was previously used by multinational companies for various types of decisions (Elbanna, 2018; Elbanna et al., 2013; Elbanna \& Fadol, 2016; Papadakis \& Barwise, 2002). This argument is based on the previous journals' assertion that different decision processes were employed in project-based companies (Slatter, 1990). The necessity of such decision processes in SMEs has been one of the limitations of the previous theory (Patzelt \& Shepherd, 2008; Shepherd, Williams \& Patzelt, 2015; Shepherd \& Rudd, 2014).

Second, this study used one decision-making dimension that makes it more specific than other studies that utilised various decision types to measure decision-making (Aravopoulou et al., 2018; Elbanna \& Child, 2007; Shepherd et al., 2015). Ahmad (1990) as well as Hughes, Tippet \& Thomas (2004) explained the way in which important project decisions were essential for a construction company's survival. Therefore, such decision-making can be figuratively used for decisions made at the strategic level, as the bare definition of strategic decision-making states that it is a type of decision that determines a firm's survival (Bingham \& Eisenhardt, 2014; Eisenhardt \& Zbaracki, 1992; Elbanna \& Fadol, 2016; Shepherd et al., 2015).

Third, the findings suggest that strategic decision-making is shaped by the variables identified by all four perspectives. Two hypotheses, supported by Papadakis (1998) and Elbanna (2007) findings, suggest that strategic decision-making is influenced by variables such as firm and environment characteristics. However, there are some incoherence with the previous findings concerning the relationship of firms with strategic decision-making. Firm characteristics negatively influence decisionmaking, as opposed to the findings of Elbanna (2007; 2016), which support the positive relationship between SDMP and firm characteristics. Contrastingly, this study shows that better firm conditions will negatively influence strategic decisionmaking.

These findings determined owing to the characteristic of construction SME' SDMP, place great emphasis on heuristic decision-making. Based on the assertions of Brouthers et al. (1998) as well as those of Busenitz and Barney (1997), SMEs were prone to using heuristic decision-making. Furthermore, Gigerenzer and Marewski (2015) explained the way in which small companies have shorter decision-making processes compared to those of bigger companies. Schwenk (1980) also explained that SMEs possess asymmetrical information. Therefore, such kind of decisionmaking is mostly affected by bounded rationality, i.e., heuristic decision-making. Moreover, Liberman-Yaconi et al. (2010) support this theory stating that limited amount of resources influences a firm's heuristic decision-making owing to the limited amount of information they possess. According to Brouthers et al. (1998), the worse off a firm's condition is, the more likely it is to use heuristic decisionmaking and vice versa.

Fourth, indigenous people prove to serve as a positive influence on a firm's SDMP. This research was conducted in a province, Papua, wherein indigenous people come 
to extensive contact with the firms. The use of the indigenous characteristic allowed the identification of a new perspective that can explain the SDMP process with regard to high indigenous influence on a firm's performance. These results are supported by previous theory suggesting that indigenous people negatively influence decision-making. According to this research, the higher the indigenous factors, the less strategic decision-making occurs (Rante \& Warokka, 2012; 2013). As explained previously, SME's strategic decision-making is prone to heuristic decision-making. Therefore, it depends on short analysis based on incomplete information (LibermanYaconi et al., 2010; Todd \& Gigerenzer, 2001). Heard et al. (2017) explained that this important issue regarding SMEs should be resolved to better explain the effect of indigenous people on a firm's decision. The better the information received through such resolution, the less likely SDMP with heuristic analysis are to occur.

Fifth, SDMP demonstrates a positive influence on the project performance. Similarly, Elbanna (2013) also found that strategic decision-making positively influences the project performance in Egypt. The project performance is closely related to the decision pertaining to the choice of the project selected. Therefore, decision-making is necessary to ensure a firm's survival in its respective field. Construction SMEs should meticulously choose the bidding price, project location, and environment conditions to finally decide whether they want to take on a government project or not (Bageis \& Fortune, 2009; Fayek, 1998; Oo et al., 2012).

Another interesting finding of our research was that no significant relationship between the institution characteristic and strategic decision-making was found. This finding is not in line with the assertions of Peng et al. (2002) and Farashahi and Hafsi (2009), which show significant influence between a firm's decision and government characteristics, along with the firm's performance. However, according to this finding, strategic decision-making is not affected by the institutional characteristic. Thus, an institution cannot determine its strategic decision-making concerning construction SMEs.

\section{Conclusion and Implication}

In general, our objective is to elucidate the aforementioned new perspective and explore the previous perspective's contributions pertaining to SDMP. This research also proves that SME's performances are positively influenced by strategic decisionmaking. There are several contributions that prove decision-making as a contributor of SME's project performance.

First, this research comprehensively explained the assumption regarding the notion that SME's performances are influenced by the strategic decision-making process. SDMP's in SMEs proves to positively influence the project performance. Our findings demonstrate that straightforward decision process of the bidding price, project location, and environmental conditions influences the performance of construction companies. Therefore, processing a project decision based on their 
previously completed project is necessary to survive the fast competition in the particular field.

Second, this research results are in line regarding environment characteristics with prior research. Environment characteristics did have a significant influence on SDMP. This is overwhelming finding for an SME's level of decision process, which is the fact that they struggle with the uncertain environment over lack of human capital and resources they managed to take the decision to be straightforward and confidence when taking a construction project. The speed decision making process indulged by limitation of information in uncertain environment does support by Cheng et al. (2019).

Third, it yielded results that are inconsistent with those of previous research (Elbanna and Said, 2007), stating that firm's condition might have a negative influence on strategic decision-making. Our research found that the existence of heuristic decision-making influences strategic decision-making. Hence, firm resource, and firm structure as they represent firm characteristics negatively influence strategic decision-making process. The fact that the bigger the company the harder decision process is encouraging these findings. The big firms tend to over complexify the process (Liberman-Yaconi et al., 2010; Gigrenzer and Marewski, 2015), therefore it negatively influences simple decision-making process.

Fourth, the findings also highlight that the new perspective sources from indigenous characteristics that prove to have a negative influence on a firm's SDMP. In these findings, our research addresses the contribution of indigenous characteristic as the new perspective that posits itself as the driver of decision-making. Moreover, the findings of our research are in line with Rante and Warokka's (2013) findings, according to which the indigenous context has an influence on a firm's performance. Our findings presented the negative relationship between indigenous characteristics and SDMP; this is because the short decision process tends to simplify the project executed alongside indigenous people. Hence, when there is a conflict, it influences the project's performance. The higher the influence of indigenous characteristics, the better-informed SME become, leading to lesser influence on SDMP along with heuristic decision-making.

Lastly, according to our findings, there is no significant relationship between institution characteristics and SDMP. This shows that government rules and affection cannot influence construction firms' project decisions. This is an overwhelming result for a developing country like Indonesia, where one believes to find government as their cushion for any project risk (Farashahi and Hafsi, 2009). But we find this result is understandable because the new rule imposing all projects will be used online bidding process therefore transparency neglect any government influence toward an SME's project decision.

\section{Limitations and Future Research Directions}


Strategic Decision Process in SME's Context: A New Perspective Using Indigenous, Institution, Firm, and Environment Characteristics

80

However, our research has certain limitations. First, all the respondents are from construction firms. Therefore, they have their own mindset concerning strategic decision context. In a future research, use of different decision type or industry might provide different perspectives regarding all determinant characteristics. Second, our study relies on a single respondent in each firm to complete the questionnaires. This method might have some bias in defining firm decision processing. For future researcher it is recommended to amplify single respondent by using interview to reduce bias in data collection. Third, for future researcher would be more accurate to understand causal relationship between strategic decision process and project performance using a longitudinal study.

\section{References:}

Agypt, B. \& Rubin, B.A. 2012. Time in the New Economy: The Impact of the Interaction of Individual and Structural Temporalities on Job Satisfaction. Journal of Management Studies, 49(2), 403-428, https://doi.org/10.1111/j.1467-6486.2011.01021.x.

Aravopoulou, E., Branine, M., Stone, M. \& Mitsakis, F. 2018. Strategic decision-making process (SDMP) in times of crisis: Evidence from Greek banks. Journal of Business and Retail Management Research, 12(4), 26-36.

Arend, R.J., Cao, X., Grego-Nagel, A., Im, J., Yang, X. \& Canavati, S. 2016. Looking Upstream and Downstream in Entrepreneurial Cognition: Replicating and Extending the Busenitz and Barney Study. Journal of Small Business Management, 54(4), 1147-1170, https://doi.org/10.1111/jsbm.12233.

Ashraf, T., Hassan, U., Ghafoor, S. \& Aslam, N. 2015. Strategic entrepreneurial decisionmaking in small firms. American Journal of Social Science Research, 1(2), 85-89. Retrieved from http://www.aiscience.org/journal/ajssr.

Åstebro, T. \& Elhedhli, S. 2006. The Effectiveness of Simple Decision Heuristics: Forecasting Commercial Success for Early-Stage Ventures. Management Science, 52(3), 395-409, https://doi.org/10.1287/mnsc.1050.0468.

Bageis, A.S. \& Fortune, C. 2009. Factors affecting the bid/no bid decision in the Saudi Arabian construction contractors. Construction Management and Economics, 27(1), 53-71, https://doi.org/10.1080/01446190802596220.

Ballesteros-Pérez, P. \& Skitmore, M. 2016. Estimating the number of new and repeated bidders in construction auctions. Construction Management and Economics, 34(12), 919-934, https://doi.org/10.1080/01446193.2016.1231408.

Basel, J.S. \& Brühl, R. 2013. Rationality and dual process models of reasoning in managerial cognition and decision making. European Management Journal, 31(6), 745-754, https://doi.org/10.1016/j.emj.2013.07.004.

Bingham, C.B. \& Eisenhardt, K.M. 2011. Rational heuristics: the 'simple rules' that strategists learn from process experience. Strategic management journal, 32(13), 1437-1464.

Boubakri, N., Mansi, S.A. \& Saffar, W. 2013. Political institutions, connectedness, and corporate risk-taking. Journal of International Business Studies, 44(3), 195-215, https://doi.org/10.1057/jibs.2013.2.

Brouthers, K.D., Andriessen, F. \& Nicolaes, I. 1998. Driving blind: Strategic decision making in small companies. Long Range Planning, 31(1), 130-138, https://doi.org/10.1016/S0024-6301(97)00099-X

Cheng, V., Rhodes, J. \& Lok, P. 2010. A framework for strategic decision making and 
performance among Chinese managers. The International Journal of Human Resource Management, 21(9), 1373-1395.

Deligianni, I., Dimitratos, P., Petrou, A. \& Aharoni, Y. 2016. Entrepreneurial orientation and international performance: The moderating effect of decision-making rationality. Journal of Small Business Management, 54(2), 462-480.

Doran, J. \& Ryan, G. 2012. Regulation and firm perception, eco-innovation and firm performance. European Journal of Innovation Management, 15(4), 421-441, https://doi.org/10.1108/1460106121127236.

Elbanna, S. 2015. Intuition in project management and missing links: Analyzing the predicating effects of environment and the mediating role of reflexivity. International Journal of Project Management, 33(6), 1236-1248, https://doi.org/10.1016/j.ijproman.2015.02.004.

Elbanna, S. 2018. The constructive aspect of political behavior in strategic decision-making: The role of diversity. European Management Journal, 36(3), 1-36.

Elbanna, S.C., Thanos, I. \& Papadakis, M.V. 2014. Understanding how the contextual variables influence political behaviour in strategic decision-making: A constructive replication. Journal of Strategy and Management, 7(3), 226-250, https://doi.org/10.1108/JSMA-02-2014-0013.

Elbanna, S. \& Child, J. 2007. The influence of decision, environmental and firm characteristics on the rationality of strategic decision-making. Journal of Management Studies, 44(4), 561-591, https://doi.org/10.1111/j.14676486.2006.00670.x.

Elbanna, S., Child, J. \& Dayan, M. 2013. A Model of Antecedents and Consequences of Intuition in Strategic Decision-making: Evidence from Egypt. Long Range Planning, 46(1-2), 149-176, https://doi.org/10.1016/j.lrp.2012.09.007.

Elbanna, S., Di Benedetto, C.A. \& Gherib, J. 2015. Do environment and intuition matter in the relationship between decision politics and success? Journal of Management and Organization, 21(1), 60-81, https://doi.org/10.1017/jmo.2014.65.

Elbanna, S. \& Fadol, Y. 2016. The role of context in intuitive decision-making. Journal of Management and Organization, 22(5), 642-661, https://doi.org/10.1017/jmo.2015.63.

Farashahi, M. \& Hafsi, T. 2009. Strategy of firms in unstable institutional environments. Asia Pacific Journal of Management, 26(4), 643-666, https://doi.org/10.1007/s10490-008-9129-9.

Garvin, T., McGee, T.K., Smoyer-Tomic, K.E. \& Aubynn, E.A. 2009. Community-company relations in gold mining in Ghana. Journal of Environmental Management, 90(1), 571-586, https://doi.org/10.1016/j.jenvman.2007.12.014.

Gigerenzer, G. \& Gaissmaier, W. 2011. Heuristic decision making. Annual review of psychology, 62, 451-482.

Gigerenzer, G. \& Marewski, J.N. 2015. Surrogate Science: The Idol of a Universal Method for Scientific Inference. Journal of Management, 41(2), 421-440, https://doi.org/10.1177/0149206314547522.

Guercini, S., La Rocca, A., Runfola, A. \& Snehota, I. 2015. Heuristics in customer-supplier interaction. Industrial Marketing Management, 48, 26-37, https://doi.org/10.1016/j.indmarman.2015.03.008.

Hair Jr, J.F., Sarstedt, M., Hopkins, L. \& G. Kuppelwieser, V. 2014. Partial least squares structural equation modeling (PLS-SEM). European Business Review, 26(2), 106121, https://doi.org/10.1108/EBR-10-2013-0128.

Heard, I., Love, P.E., Sing, M.C. \& Goerke, V. 2017. Learning to build relationships for a 
Strategic Decision Process in SME's Context: A New Perspective Using Indigenous, Institution, Firm, and Environment Characteristics

82

better Australia: Indigenous reconciliation in action in the construction and resource sectors. Construction Innovation, 17(1), 4-24.

Huang, P., Ceccagnoli, M., Forman, C. \& Wu, D.J. 2013. Appropriability Mechanisms and the Platform Partnership Decision: Evidence from Enterprise Software.

Management Science, 59(1), 102-121, https://doi.org/10.1287/mnsc.1120.1618.

Jansen, R.J.G., Curşeu, P.L., Vermeulen, P.A.M., Geurts, J.L.A. \& Gibcus, P. 2011. Social capital as a decision aid in strategic decision-making in service organizations.

Management Decision, 49(5), 734-747, https://doi.org/10.1108/00251741111130823.

Jarkas, A.M., Mubarak, S.A. \& Kadri, C.Y. 2014. Critical Factors Determining Bid/No Bid Decisions of Contractors in Qatar. Journal of Management in Engineering, 30(4), 05014007, https://doi.org/10.1061/(ASCE)ME.1943-5479.0000223.

Liberman-Yaconi, L., Hooper, T. \& Hutchings, K. 2010. Toward a Model of Understanding Strategic Australian Information Technology Sector. Journal of Small Business Management, 48(1), 70-95, https://doi.org/10.1111/j.1540-627X.2009.00287.x.

Lin, P.T., Li, B. \& Bu, D. 2015. The relationship between corporate governance and community engagement: Evidence from the Australian mining companies. Resources Policy, 43(January 2014), 28-39, https://doi.org/10.1016/j.resourpol.2014.11.00.

Ling, F.Y.Y. \& Li, S. 2012. Using social network strategy to manage construction projects in China. International Journal of Project Management, 30(3), 398-406, https://doi.org/10.1016/j.ijproman.2011.05.010.

Makadok, R., Burton, R. \& Barney, J. 2018. A practical guide for making theory contributions in strategic management. Strategic Management Journal, 39(6), 15301545, https://doi.org/10.1002/smj.2789.

Moser, R., Kuklinski, C.P.J.W. \& Weidmann, M. 2014. The impact of institutions on the resources of foreign companies: The case of third-party logistics service providers in Russia. Journal for East European Management Studies, 19(3), 305-326, https://doi.org/10.1688/JEEMS-2014-03-Moser.

Oo, B.L., Lo, H.P. \& Lim, B.T.H. 2012. The effect of bidding success in construction bidding. Engineering, Construction and Architectural Management, 19(1), 25-39, https://doi.org/10.1108/09699981211192553.

Papadakis, V.M. 1998. Strategic Investment Decision Processes and Organizational Performance: An Empirical Examination. British Journal of Management, 9, 115132.

Papadakis, V.M. 2006. Do CEOs shape the process of making strategic decisions? Evidence from Greece. Management Decision, 44(3), 367-394, https://doi.org/10.1108/00251740610656269

Papadakis, V.M. \& Barwise, P. 2002. How much do CEOs and top managers matter in strategic decision-making? British Journal of Management, 13(1), 83-95, https://doi.org/10.1111/1467-8551.00224.

Patzelt, H. \& Shepherd, D.A. 2008. The Decision to Persist with Underperforming Alliances: The Role of Trust and Control. Journal of Management Studies, 45(7), 1217-1243.

Papulova, Z. \& Gazova, A. 2016. Role of strategic analysis in strategic decision-making. Procedia Economics and Finance, 39, 571-579.

Prabhudesai, R., Prasad, C.V., Walwadkar, S. \& Agrawal, S. 2017. Analyzing the Impact of Perceived Environmental Uncertainty on SME Alliance Formation: An Indian Perspective. International Journal of Global Business and Competitiveness, 12(1), $37-43$. 
Rante, Y. \& Warokka, A. 2012. The Triple Nexus of Indigenous Economic Growth and SMEs Performance: Local Culture, Government Role, and Entrepreneurial Behavior. Journal of Innovation Management in Small \& Medium Enterprises, https://doi.org/10.5171/2013.360774.

Rante, Y. \& Warokka, A. 2013. The Interrelated Nexus of Indigenous Economic Growth and Small Business Development: Do Local Culture, Government Role, and Entrepreneurial Behavior Play the Role? Journal of Innovation Management in Small \& Medium Enterprises, https://doi.org/10.5171/2013.360774.

Reggers, A., Grabowski, S., Wearing, S.L., Chatterton, P. \& Schweinsberg, S. 2016. Exploring outcomes of community-based tourism on the Kokoda Track, Papua New Guinea: a longitudinal study of Participatory Rural Appraisal techniques. Journal of Sustainable Tourism, https://doi.org/10.1080/09669582.2016.1145229.

Shepherd, D.A. \& Sharfman, M.P. 2011. Erratic strategic decisions: when and why managers are inconsistent in strategic decision making. Strategic Management Journal, 32, 683-704, https://doi.org/10.1002/smj.

Shepherd, D.A., Williams, T.A. \& Patzelt, H. 2015. Thinking About Entrepreneurial Decision Making: Review and Research Agenda. Journal of Management, 41(1), 136, https://doi.org/10.1177/0149206314541153.

Shepherd, N.G. \& Rudd, J.M. 2014. The influence of context on the strategic decisionmaking process: A review of the literature. International Journal of Management Reviews, 16(3), 340-364, https://doi.org/10.1111/ijmr.12023.

Souitaris, V. \& Maestro, B.M.M. 2010. Polychronicity in top management teams: the impact on strategic decision processes and performance of new technology ventures. Strategic management journal, 652-678, https://doi.org/10.1002/smj.

Weathers, D., Sharma, S. \& Niedrich, R.W. 2005. The impact of the number of scale points, dispositional factors, and the status quo decision heuristic on scale reliability and response accuracy. Journal of Business Research, 58, 1516-1524, https://doi.org/10.1021/np50040a032.

Wiklund, J. \& Shepherd, D. 2005. Entrepreneurial orientation and small business performance: a configurational approach. Journal of Business Venturing, 20, 71-91, https://doi.org/10.1016/j.jbusvent.2004.01.001. 